BMJ Paediatrics Open

\section{Comparison of pulse oximetry and earlobe blood gas with CO-oximetry in children with sickle cell disease: a retrospective review}

To cite: Arigliani M, Zheng S, Ruiz G, et al. Comparison of pulse oximetry and earlobe blood gas with C0-oximetry in children with sickle cell disease: a retrospective review. BMJ Paediatrics Open 2020;4:e000690. doi:10.1136/ bmjpo-2020-000690

Partial results from the present study have been previously presented in form of abstracts at international meetings.

Received 2 April 2020

Revised 4 May 2020

Accepted 5 May 2020

Check for updates

(c) Author(s) (or their employer(s)) 2020. Re-use permitted under CC BY-NC. No commercial re-use. See rights and permissions. Published by BMJ

${ }^{1}$ Paediatric Respiratory Medicine and Lung Transplantation, Great Ormond Street Hospital for Children, London, United Kingdom

${ }^{2}$ Department of Paediatric Respiratory Medicine, King's College Hospital NHS Foundation Trust, London, UK

${ }^{3}$ Department of Paediatric Haematology, King's College Hospital NHS Foundation Trust, London, UK

${ }^{4}$ King's College London, London, United Kingdom

Correspondence to Dr Atul Gupta; atul.gupta@kcl. ac.uk

\section{ABSTRACT}

Objectives To investigate the agreement between pulse oximetry $\left(\mathrm{SpO}_{2}\right)$ and oxygen saturation $\left(\mathrm{SaO}_{2}\right)$ measured by $\mathrm{CO}$-oximetry on arterialised earlobe blood gas (EBG) in children and adolescents with sickle cell disease (SCD).

Design and setting We retrospectively reviewed 39 simultaneous and paired $\mathrm{SaO}_{2} \mathrm{EBG}$ and $\mathrm{SpO}_{2}$ measurements from 33 ambulatory patients with SCD (32 subjects with Haemoglobin SS and one with Haemoglobin $\mathrm{SB}^{+}, 52 \%$ male, mean $\pm \mathrm{SD}$ age $11.0 \pm 3.6$, age range 5-18) Measurements were performed between 2012 and 2015 when participants were asymptomatic. Hypoxaemia was defined as $\mathrm{SaO}_{2} \leq 93 \%$. A Bland-Altman analysis was performed to assess the accuracy of $\mathrm{SpO}_{2}$ as compared with $\mathrm{EBG} \mathrm{SaO}$.

Results The mean $\pm \mathrm{SD} \mathrm{SpO}$ and $\mathrm{SaO}_{2}$ values in the same patients were, respectively, $93.6 \% \pm 3.7 \%$ and $94.3 \% \pm 2.9 \%$. The bias $\mathrm{Sp} 0-\mathrm{SaO}$ was $-0.7 \%$ (95\% limits of agreement from $-5.4 \%$ to $4.1 \%$ ) and precision was $2.5 \%$. In 9/39 (23\%) cases, the difference in $\mathrm{SpO}_{2}-\mathrm{SaO}_{2}$ was greater than the expected error range $\pm 2 \%$, with $\mathrm{SaO}$ more often underestimated by $\mathrm{SpO}_{2}(6 / 9)$, especially at $\mathrm{SpO}_{2}$ values $\leq 93 \%$. Thirteen participants $(33 \%)$ were hypoxaemic. The sensitivity of $\mathrm{SpO}$ for hypoxaemia was $100 \%$, specificity $85 \%$ and positive predictive value $76 \%$. Conclusions Pulse oximetry was inaccurate in almost a quarter of measurements in ambulatory paediatric patients with $\mathrm{SCD}$, especially at $\mathrm{Sp}_{2}$ values $\leq 93 \%$. In these cases, oxygen saturation can be confirmed through EBG COoximetry, which is easier to perform and less painful than traditional arterial blood sampling.

\section{INTRODUCTION}

Sickle cell disease (SCD) is an inherited disorder of haemoglobin $(\mathrm{Hb})$, characterised by recurrent episodes of acute illness related to red blood cells sickling and subsequent vaso-occlusion. ${ }^{1}$ Hypoxaemia is a predictor of vaso-occlusive pain ${ }^{2}$ and may be an early sign of acute chest syndrome (ACS ${ }^{3}$; therefore, accurate measurement of arterial oxygen saturation is important to guide management in both ambulatory and emergency setting. ${ }^{4}$ The most accurate measure

\section{What is known about the subject?}

Accurate measurement of oxygen saturation is important in sickle cell disease (SCD).

- Discrepancies in oxygen saturation have been shown between pulse oximetry and $\mathrm{CO}$-oximetry on arterial blood samples in children with SCD.

\section{What this study adds?}

In clinically stable children with SCD, pulse oximetry does not accurately reflect haemoglobin saturation, especially at $\mathrm{SpO}_{2}$ values $\leq 93 \%$.

- In these cases, C0-oximetry on arterialised earlobe blood is an easier to obtain alternative to traditional arterial blood sampling.

of oxyhaemoglobin is by CO-oximetry on arterial blood $\left(\mathrm{SaO}_{2}\right)$, which is reliable in individuals with either predominant $\mathrm{HbA}$ or HbS. ${ }^{56}$ Minute-by-minute changes of oxygen saturation are detected with non-invasive pulse oximetry $\left(\mathrm{SpO}_{2}\right)$ that shows a good correlation with CO-oximetry in individuals with normal $\mathrm{Hb}$ phenotype. ${ }^{7}$ However, people with SCD represent a different population in which previous small studies have shown some discrepancies between $\mathrm{SpO}_{2}$ and $\mathrm{SaO}_{2}$ measured by CO-oximetry. ${ }^{8-12}$ Treatment decisions in patients with SCD are often influenced by $\mathrm{SpO}_{2}$ findings, especially in the acute care setting where inaccuracies can result in misdiagnosis or mismanagement. For example, during an ACS episode, failure to detect hypoxaemia may delay the start of oxygen supplementation, which is a mainstay of supportive therapy. ${ }^{13}$ On the other hand, underestimation of oxygen saturation by $\mathrm{SpO}_{2}$ may lead the clinician to an inappropriate use of oxygen supplementation, with detrimental effects on erythropoiesis. ${ }^{14}$ 
Although arterial gas analysis with CO-oximetry is the gold standard to evaluate oxygen saturation in patients with SCD, the procedure is distressing and poorly tolerated in children. Measuring $\mathrm{SaO}_{2}$ by CO-oximetry on arterialised earlobe blood gas (EBG) is an alternative procedure that shows reasonable agreement with traditional arterial blood gas, especially for low arterial $\mathrm{PO}_{9}$ values that are more relevant in the clinical setting. ${ }^{15} 16$ The use of EBG in patients with SCD is attractive as it allows to reduce discomfort and pain ${ }^{17}$ : a valuable target in population at risk of psychological complications related to the high burden of pain experienced. ${ }^{18}$

This retrospective study sought to investigate the agreement between $\mathrm{SpO}_{2}$ and $\mathrm{SaO}_{2}$ measured on EBG with CO-oximetry in ambulatory paediatric patients with $\mathrm{SCD}$. We hypothesised that $\mathrm{SpO}_{2}$ would not be highly accurate in predicting $\mathrm{SaO}_{2}$. Since the presence of acute comorbidity might have affected these measurements, especially for $\mathrm{SpO}_{2}$ whose accuracy worsens when $\mathrm{SaO}_{2}$ is lower than $90 \%,{ }^{19}$ we limited our analysis to patients who did not have acute symptoms at the time of evaluation.

\section{METHODS}

We retrospectively reviewed our electronic database of patients with SCD aged 5-18 years with respiratory issues attending the paediatric respiratory clinic at King's College Hospital, London, from 1 February 2012 to 1 August 2015. Evaluation of $\mathrm{SaO}_{2}$ through EBG with CO-oximetry, in addition to $\mathrm{SpO}_{2}$, represents a standard clinical practice in this clinic and it was routinely proposed to the attending patients. Those who accepted to undergo the EBG and had a successful measure of $\mathrm{SaO}_{2}$ were included in the analysis. Reasons for referral to the respiratory clinic were mainly asthma symptoms and sleep disordered breathing (eg, loud snoring, witnessed apnoeas, restless sleep and mouth breathing). Participants had simultaneous EBG with CO-oximetry and $\mathrm{SpO}_{2}$ measurements taken in room air during their visit. Only patients who had paired and valid $\mathrm{EBG}$ and $\mathrm{SpO}_{2}$ data taken during the same visit were included in the analysis. None of the subjects enrolled were suffering from SCDrelated acute events (eg, painful crises, ACS, etc) at the time of evaluation. Pulse oximetry was performed using a Nonin $\mathrm{GO}_{2}$ pulse oximeter (Nonin, Plymouth, Minnesota, USA). $\mathrm{SpO}_{2}$ was recorded after at least $2 \mathrm{~min}$ of stable $\mathrm{SpO}_{2}$ readings and a clear pulsatile photoplethysmographic signal. EBG sampling was conducted at rest after 10-20 min of inactivity by an experienced operator. Rubefacient cream (thurfyl nicotinate) was applied to the earlobe in order to obtain local vasodilation and was left for $10 \mathrm{~min}$ prior to sampling. The rubefacient was then removed and the earlobe was rubbed vigorously with a gauze swab. Using a No. 15 Swann Morton scalpel blade, an incision was made in the ear lobe approximately $3 \mathrm{~mm}$ from the lower tip of the pinna to a depth of approximately $3 \mathrm{~mm}$ or deep enough to ensure free, rapid blood flow. After discarding the initial drop, the sample was collected in a preheparinised plastic capillary tube, taking care to avoid the formation of air bubbles. Samples were discarded if they contained air bubbles or if blood flow was slow or showed signs of clotting. Samples were immediately analysed using an ABL90 Flex blood gas analyzer with CO-oximetry (Radiometer Medical ApS, Denmark). $\mathrm{SaO}_{2}, \mathrm{pH}, \mathrm{PaO}_{2}$ and $\mathrm{PaCO}_{2}$ values were recorded.

Data analysed in this study were collected at the time as part of standard clinical care.

\section{This research was done without patient involvement}

Patients were not invited to comment on the study design and were not consulted to develop patient relevant outcomes or interpret the results. Patients were not invited to contribute to the writing or editing of this document for readability or accuracy.

\section{Power of the study and statistical analysis}

Comparison of $36 \mathrm{SpO}_{2}$ and $36 \mathrm{SaO}_{2}$ measurements in the same patients would provide $80 \%$ power at the $5 \%$ significance level (two tails) to detect a difference of $2 \%^{7}$ between mean $\mathrm{SpO}_{2}(92 \%)^{20}$ and $\mathrm{SaO}_{2}(94 \%)$ with a $\mathrm{SD}=3 \%$ for both techniques. A Bland-Altman analysis was performed, ${ }^{21}$ computing the mean difference $\mathrm{SpO}_{2}$ $-\mathrm{SaO}_{2}$ ('bias') with the $95 \%$ limits of agreement (the interval of values within which $95 \%$ of the differences between $\mathrm{SpO}_{2}-\mathrm{SaO}_{2}$ lie) and the $\mathrm{SD}$ of these differences ('precision'). The expected bias between $\mathrm{SpO}_{2}$ and $\mathrm{SaO}_{2}$ according to most factures should be $\leq 2 \%$, with precision of $\leq 4 \%{ }^{7}$ Hypoxaemia was defined as a $\mathrm{SaO}_{2}$ measured by EBG CO-oximetry $\leq 93 \%$. This cut-off has been associated with pathophysiological and clinical consequences in patients with SCD and chronic hypoxaemia. ${ }^{22}{ }^{23} \mathrm{In}$ order to evaluate the accuracy of $\mathrm{SpO}_{2}$ to detect hypoxaemia, the sensitivity (the percentage of subjects with $\mathrm{SpO}_{2} \leq 93 \%$ and $\mathrm{SaO}_{2} \leq 93 \%$ of all subjects with an $\mathrm{SaO}_{2}$ $\leq 93 \%$ ), specificity (the percentage of subjects with $\mathrm{SpO}_{2}$ $>93 \%$ and $\mathrm{SaO}_{2}>93 \%$ of all subjects with an $\mathrm{SaO}_{2}>93 \%$ ), positive predictive value (the percentage of subjects with $\mathrm{SaO}_{2} \leq 93 \%$ of all patients with $\mathrm{SpO}_{2} \leq 93 \%$ ) and negative predictive value (the percentage of subjects with $\mathrm{SaO}_{2}$ $>93 \%$ of all patients with $\mathrm{SpO}_{2}>93 \%$ ) were calculated. A $p$ value $<0.05$ was considered as statistically significant. Statistical analysis was performed with GraphPad Prism V.8.00 (GraphPad Software, California, USA).

\section{RESULTS}

We analysed 39 simultaneous paired $\mathrm{SaO}_{2}$ and $\mathrm{SpO}_{2}$ readings from 33 children with SCD (boys $52 \%$ ). Mean \pm SD age at the time of evaluation was $11.0 \pm 3.6$ and distribution by ethnicity was $90 \%$ black African, $7 \%$ black Caribbean and $3 \%$ mixed Asian. Thirty-two participants were HbSS and one $\mathrm{HbS} / \mathrm{B}^{+}$. Almost half of the patients $(48 \%, 16 / 33)$ were on hydroxyurea therapy and two patients were under chronic transfusion regime.

The mean $\pm \mathrm{SD} \mathrm{SaO}_{2}$ was $94.3 \% \pm 2.9 \%$ (range $87 \%-98 \%$ ) and mean $\mathrm{SpO}_{2}$ was $93.6 \% \pm 3.7 \%$ (range $83 \%-100 \%$ ). 


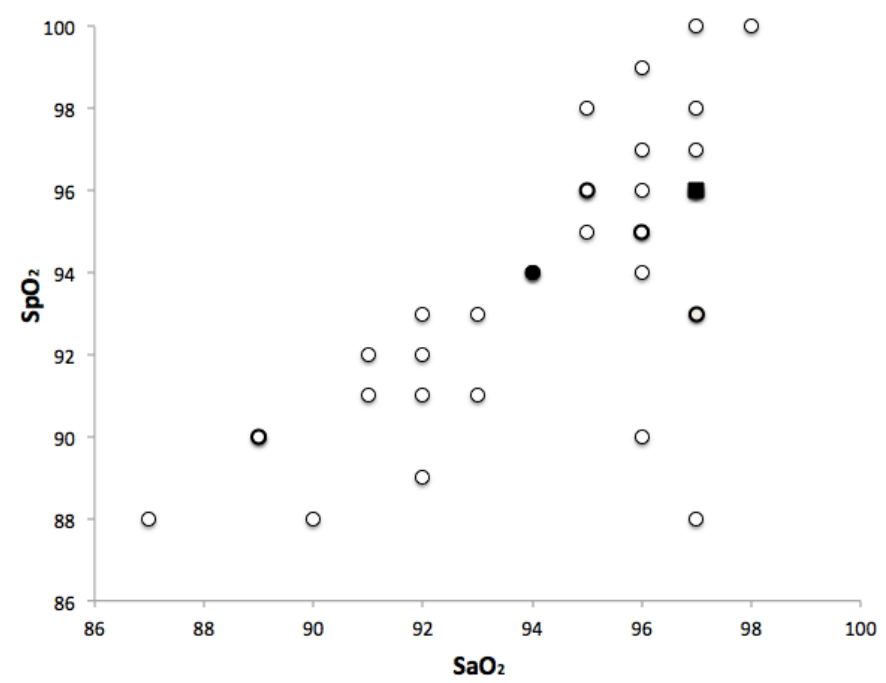

Figure 1 Scatter plot of 39 simultaneous earlobe blood gas $\mathrm{SaO}_{2}$ and $\mathrm{SpO}_{2}$ records in 33 patient with sickle cell disease aged 5-18 years. There are some overlapping values. The blank circles with normal border represent one observation, the blank circles with bold border represent two observations, the black circles indicate three observations and the black square four observations.

A scatter plot of $\mathrm{SaO}_{2}$ versus $\mathrm{SpO}_{2}$ values from simultaneous records in each patient is represented in figure 1. The bias between $\mathrm{SpO}_{2}$ and $\mathrm{SaO}_{2}$ measured by EBG with CO-oximetry was $-0.7 \%$ and the precision $2.5 \%(95 \%$ limits of agreement from -5.4 to 4.1 ; figure 2 ). In $23 \%$ of cases $(\mathrm{n}=9)$, difference $\mathrm{SpO}_{2}-\mathrm{SaO}_{2}$ was greater than expected bias of $\pm 2 \% .^{7}$ Of these, in three patients, oxygen saturation was overestimated by $\mathrm{SpO}_{2}$ and in six underestimated (figure 2).

Thirteen participants $(33 \%)$ were hypoxaemic $\left(\mathrm{SaO}_{2}\right.$ $\leq 93 \%$ at EBG CO-oximetry), whereas a $\mathrm{SpO}_{2} \leq 93 \%$ was found in 17 participants (43.5\%). Among the 13 patients with $\mathrm{SCD}$ and $\mathrm{SaO}_{2} \leq 93 \%, 12 / 13(92 \%)$ had a partial pressure of oxygen $\left(\mathrm{PaO}_{2}\right)>70 \mathrm{~mm} \mathrm{Hg}$, indicating a rightshifted oxyhaemoglobin dissociation curve (normally, for a given $\mathrm{SaO}_{2}$ of $93 \%$, a $\mathrm{PaO}_{2}$ of $70 \mathrm{~mm} \mathrm{Hg}$ would be expected).

The sensitivity of pulse oximetry to detect hypoxaemia (using EBG CO-oximetry $\mathrm{SaO}_{2}$ as standard) was $100 \%$ (95\% CIs $77 \%$ to $100 \%$ ), specificity $85 \%$ (95\% CI $66 \%$ to $94 \%$ ), positive predictive value $76 \%$ (95\% CI $53 \%$ to $90 \%$ ) and negative predictive value $100 \%$ (95\% CI $85 \%$ to $100 \%)$.

\section{DISCUSSION}

We evaluated the accuracy of pulse oximetry in predicting oxygen saturation as measured by CO-oximetry on arterialised capillary blood from the earlobe. Although the bias (mean difference) between $\mathrm{SpO}_{2}$ and $\mathrm{SaO}_{2}$ was low $(-0.7 \%)$, we found that pulse oximetry was less accurate than expected (error range within $\pm 2 \%$ compared with $\left.\mathrm{SaO}_{2}\right)$ in almost a quarter $(9 / 39)$ of measurements in ambulatory paediatric patients with SCD.
The accuracy of capillary blood gas compared with arterial gas analysis has been mainly evaluated by studies performed in the intensive care setting and their results have been compared in a meta-analysis showing that EBG may be appropriate as a replacement for arterial $\mathrm{SaO}_{q}$, unless precision is needed (adjusted $\mathrm{r}^{2}=0.88$; mean bias $=3.8 \mathrm{~mm} \mathrm{Hg}$ ) ${ }^{16}$ Interestingly from a clinical perspective, the meta-analysis showed that the accuracy of EBG in predicting arterial $\mathrm{PaO}_{2}$ improves in hypoxic conditions. Although there are no published data regarding the SCD population, the accuracy of EBG with CO-oximetry in this group is expected to be similar to that found in subjects without SCD.

Noticeably, the bias $(-0.7 \%)$ and precision $(2.5 \%)$ of $\mathrm{SpO}_{2}$ versus $\mathrm{SaO}_{2}$ were lower than reported in previous studies comparing pulse oximetry and arterial blood gas with CO-oximetry in patients with SCD in both the acute $^{8-102425}$ and outpatient ${ }^{1112}$ setting. Available evidence indicates conflicting data regarding the tendency of $\mathrm{SpO}_{2}$ to provide results higher or lower than $\mathrm{SaO}_{2}$ in the same patients, whereas in the present study $\mathrm{SaO}_{2}$ was more frequently underestimated (of at least $2 \%$ ) than overestimated by $\mathrm{SpO}_{2}$ (figure 2). Inaccuracy of pulse oximetry was more pronounced at lower $\mathrm{SpO}_{2}$ values $\leq 93 \%$, consistently with previous findings in adult patients with $\mathrm{ACS}^{9}$ and in outpatient children with SCD. ${ }^{11}$ This finding suggests that an $\mathrm{SpO}_{2} \leq 93 \%$ in a child with $\mathrm{SCD}$ should be confirmed through a $\mathrm{SaO}_{2}$ assessment. We suggest this can be preferably done through EBG with CO-oximetry, in order to limit pain and discomfort for the patient.

Pulse oximetry did not miss any case of hypoxaemia $\left(\mathrm{SaO}_{2} \leq 93 \%\right)$, but it provided some false-positive results

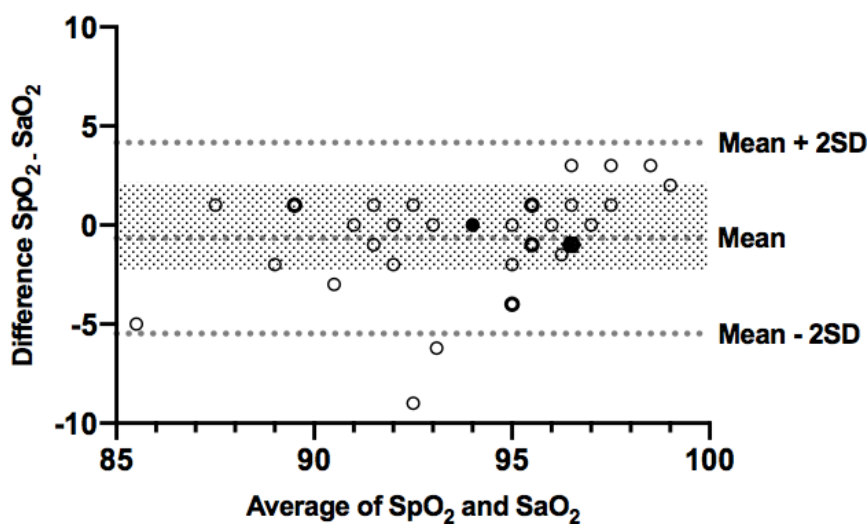

Figure 2 Bland-Altman plot showing the average values of simultaneous $\mathrm{SaO}_{2}$ by earlobe blood gas and $\mathrm{SpO}_{2}$ for each measurement in patient with sickle cell disease $(X-$ axis) versus the differences ( $Y$-axis). Broken lines indicates mean difference $(-0.7 \%)$ and limits of agreement $(-5.4$ to $+4.1 \%$; mean $\pm 2 \mathrm{SD}$ ). Shaded region represents a difference of $\pm 2 \%$, which is the accepted error range for $\mathrm{SpO}_{2}$. A total of 39 paired measurements were plotted but only 30 points are visible, as there are some overlapping values. The blank circles with normal border represent one observation, the blank circles with bold border represent two observations, the black circles indicate three observations and the black hexagon four observations. 
(specificity $85 \%$ ) and its positive predictive value for hypoxaemia was only $76 \%$, further indicating the need to evaluate $\mathrm{SaO}_{2}$ in patients with $\mathrm{SCD}$ with $\mathrm{SpO}_{2}$ values in the hypoxaemic range $\left(\mathrm{SpO}_{2} \leq 93 \%\right)$. A former study that adopted the traditional definition of hypoxaemia based on $\mathrm{PaO}_{2} \leq 70 \mathrm{~mm} \mathrm{Hg}$ (corresponding to $\mathrm{SaO}_{2} \leq 93 \%$ in a normal oxyhaemoglobin curve) found that none of nine patients with $\mathrm{SCD}$ and $\mathrm{SpO}_{2} \leq 93 \%$ had $\mathrm{PaO}_{2} \leq 70 \mathrm{~mm} \mathrm{Hg}$. Similarly, in our study, only 1 out of 17 participants with $\mathrm{SpO}_{2} \leq 93 \%$ had a $\mathrm{PaO}_{2} \leq 70 \mathrm{~mm} \mathrm{Hg}$, indicating that the oxyhaemoglobin dissociation curve was right shifted, with a lower $\mathrm{SaO}_{2}$ for a given $\mathrm{PaO}_{2}$ compared with a normal curve. ${ }^{24-26}$ In light of this evidence, we think that hypoxaemia in patients with SCD should be defined according to $\mathrm{a} \mathrm{SaO}_{2}$ cut-off (as in the present study) rather than relying on $\mathrm{PaO}_{2}$ values, as $\mathrm{SaO}_{2}$ will better reflect the amount of oxygen that can be transported to the tissues (depending also on cardiac output, $\mathrm{Hb}$ concentration, etc) ${ }^{27}$

There are several factors that can contribute to unreliable pulse oximeter results in children with SCD. First, the oxyhaemoglobin dissociation curve tends to be right shifted when HbS polymerises. ${ }^{28}$ Moreover, dysfunctional $\mathrm{Hb}$ (carboxyhaemoglobin and methaemoglobin) are elevated in the presence of intravascular haemolysis and, since they adsorb light at similar wavelengths as oxygenated and deoxygenated, can affect $\mathrm{SpO}_{2}$ readings of convectional pulse oximeters. ${ }^{29}$ Furthermore, the high frequency of dark skin among patients with SCD can be an risk factor for poor accuracy of $\mathrm{SpO}_{2}$ in patients with hypoxaemia $^{30}$ and, finally, accuracy of $\mathrm{SpO}_{2}$ is lower at $\mathrm{SaO}_{2}$ values $<90 \%$, a range of oxygen saturation often seen during ACS episodes. ${ }^{9}$

A strength of this study is that, to the best of the authors' knowledge, is the largest comparison of $\mathrm{SpO}_{2}$ and $\mathrm{SaO}_{2}$ values in patients with SCD published so far and the first to have been specifically powered for this outcome. Moreover, this is also the first report of EBG with CO-oximetry in patients with SCD.

There were also several limitations. Accuracy of pulse oximeter was evaluated only in comparison to EBG with CO-oximetry, without performing arterial blood gas with CO-oximetry, which represents the gold standard. However, the acceptable agreement demonstrated between CO-oximetry performed on EBG and arterial blood samples ${ }^{16}$ should guarantee adequate reliability of the results. At this regards, we had a limited number of $\mathrm{EBG} \mathrm{SaO}_{2}$ values $<90 \%(6 / 39,15 \%)$. As known from the literature ${ }^{30}$ and confirmed by our data (figure 2), the accuracy of pulse oximetry is poorer at these low oxygen saturation levels. The inclusion of a higher number of patients with hypoxaemia with SCD, for example, enrolling inpatients with acute clinical manifestations that have more often low $\mathrm{SaO}_{2}$, would have probably negatively affected the overall agreement between $\mathrm{SaO}_{2}$ and $\mathrm{SpO}_{2}$. However, including acutely ill patients would have been beyond the scope of this study that aimed to compare the use of EBG and pulse oximetry in an outpatient, non-critical, setting.
$\mathrm{Hb}$ values were not recorded at the time of oxygen saturation measurement, precluding the possibility of evaluating the relationship between $\mathrm{SpO}_{2}-\mathrm{SaO}_{2}$ values and $\mathrm{Hb}$ concentration. The inclusion of patients with SCD with respiratory issues and the absence of individuals with acute comorbidity do not allow to extend the findings to the entire SCD population. Finally, due to the retrospective design, outcomes related to pain and acceptability of the EBG procedure in patients with SCD could not be evaluated.

\section{CONCLUSIONS}

Although the bias between $\mathrm{SpO}_{2}$ and $\mathrm{SaO}_{2}$ from arterialised earlobe gas analysis with CO-oximetry was rather small, pulse oximeter was inaccurate (differences at least $\pm 2 \%$ ) in almost a quarter of ambulatory paediatric patients with $\mathrm{SCD}$, especially for $\mathrm{SpO}_{2}$ values $\leq 93 \%$. Clinician should be aware that when such low $\mathrm{SpO}_{2}$ values are detected in ambulatory patients with SCD, before taking major clinical decision based on these findings, they should be confirmed by an $\mathrm{SaO}_{2}$ assessment, due to the possibility of false-positive results. Evaluation of $\mathrm{SaO}_{2}$ in children with SCD can be performed, in alternative to traditional arterial blood sampling, through arterialised EBG with CO-oximetry that reduces pain and discomfort for the patient. ${ }^{16}$

Future studies should assess the agreement between pulse oximetry and arterialised EBG with CO-oximetry in patients with SCD acutely ill (ideally, also including the gold standard measure of $\mathrm{SaO}_{0}$ from arterial blood sampling), and whether the use of EBG in addition to $\mathrm{SpO}_{2}$ for evaluating oxygen saturation has any impact on clinical outcomes (length of hospitalisation, use of oxygen supplementation and requirement for noninvasive and invasive ventilation). Furthermore, it should be also evaluated if the use of EBG instead of arterial sampling for assessing oxygen saturation in acutely ill patients with SCD improves significantly the burden of pain and discomfort suffered during hospitalisation.

\section{Twitter Atul Gupta $\square @$ Lungclinic $\square$}

Acknowledgements We adcknoweldge Mr Alan Lunt for his contribution to data collection.

Contributors MA performed the analysis and wrote the manuscript. SZ designed the data collection instruments, coordinated and undertook data collection, contributed to the manuscript and approved the final manuscript as submitted. AL, GR, SC, CJB, DR reviewed and revised the initial manuscript, and approved the final manuscript as submitted. AG conceptualised and designed the study, reviewed and revised the initial manuscript, and approved the final manuscript as submitted.

Funding The authors have not declared a specific grant for this research from any funding agency in the public, commercial or not-for-profit sectors.

Competing interests None declared.

Patient and public involvement Patients and/or the public were not involved in the design, or conduct, or reporting, or dissemination plans of this research.

Patient consent for publication Not required.

Provenance and peer review Not commissioned; externally peer reviewed.

Data availability statement Data are available upon reasonable request. Deidentified participant data are available upon reasonable request to the corresponding author (atul.gupta@kcl.ac.uk) 
Open access This is an open access article distributed in accordance with the Creative Commons Attribution Non Commercial (CC BY-NC 4.0) license, which permits others to distribute, remix, adapt, build upon this work non-commercially, and license their derivative works on different terms, provided the original work is properly cited, appropriate credit is given, any changes made indicated, and the use is non-commercial. See: http://creativecommons.org/licenses/by-nc/4.0/.

ORCID iDs

Michele Arigliani http://orcid.org/0000-0002-5366-4594

Sean Zheng http://orcid.org/0000-0002-5762-6392

Subarna Chakravorty http://orcid.org/0000-0003-3862-3230

Atul Gupta http://orcid.org/0000-0002-1610-0335

\section{REFERENCES}

1 Rees DC, Williams TN, Gladwin MT. Sickle-Cell disease. The Lancet 2010;376:2018-31 https://doi.org/

2 Hargrave DR, Wade A, Evans JPM, et al. Nocturnal oxygen saturation and painful sickle cell crises in children. Blood 2003;101:846-8 https://doi.org/

3 Vichinsky EP, Neumayr LD, Earles AN, et al. Causes and outcomes of the acute chest syndrome in sickle cell disease. N Engl J Med 2000;342:1855-65.

4 Caboot JB, Allen JL. Hypoxemia in sickle cell disease: significance and management. Paediatr Respir Rev 2014;15:17-23 https://doi. org/

5 Sunshine HR, Hofrichter J, Ferrone FA, et al. Oxygen binding by sickle cell hemoglobin polymers. J Mol Biol 1982;158:251-73 https://doi.org/

6 DeYoung A, Noble RW. Oxygen binding to sickle cell hemoglobin. Methods Enzymol 1981;76:792-803 https://doi.org/

7 Fouzas S, Priftis KN, Anthracopoulos MB. Pulse oximetry in pediatric practice. Pediatrics 2011;128:740-52 https://doi.org/

8 Craft JA, Alessandrini E, Kenney LB, et al. Comparison of oxygenation measurements in pediatric patients during sickle cell crises. J Pediatr 1994;124:93-5 https://doi.org/

9 Kress JP, Pohlman AS, Hall JB. Determination of hemoglobin saturation in patients with acute sickle chest syndrome: a comparison of arterial blood gases and pulse oximetry. Chest 1999;115:1316-20 https://doi.org/

10 Ahmed S, Siddiqui AK, Sison CP, et al. Hemoglobin oxygen saturation discrepancy using various methods in patients with sickle cell vaso-occlusive painful crisis. Eur J Haematol 2005;74:309-14 https://doi.org/

11 Blaisdell CJ, Goodman S, Clark K, et al. Pulse oximetry is a poor predictor of hypoxemia in stable children with sickle cell disease. Arch Pediatr Adolesc Med 2000;154:900-3.

12 Needleman JP, Setty BN, Varlotta L, et al. Measurement of hemoglobin saturation by oxygen in children and adolescents with sickle cell disease. Pediatr Pulmonol 1999;28:423-8.
13 Yawn BP, Buchanan GR, Afenyi-Annan AN, et al. Management of sickle cell disease: summary of the 2014 evidence-based report by expert panel members. JAMA 2014;312:1033-48 https://doi. org/

14 Embury SH, Garcia JF, Mohandas N, et al. Effects of oxygen inhalation on endogenous erythropoietin kinetics, erythropoiesis, and properties of blood cells in sickle-cell anemia. N Engl J Med 1984;311:291-5 https://doi.org/

15 Pitkin AD, Roberts CM, Wedzicha JA. Arterialised earlobe blood gas analysis: an underused technique. Thorax 1994;49:364-6 https://doi. org/

16 Zavorsky GS, Cao J, Mayo NE, et al. Arterial versus capillary blood gases: a meta-analysis. Respir Physiol Neurobiol 2007;155:268-79 https://doi.org/

17 Dar K, Williams T, Aitken R, et al. Arterial versus capillary sampling for analysing blood gas pressures. BMJ 1995;310:24-5 https://doi. org/

18 Anie KA. Psychological complications in sickle cell disease. Br J Haematol 2005;129:723-9 https://doi.org/

19 Jubran A. Pulse oximetry. Crit Care 2015;19:272 https://doi.org/

20 Homi J, Levee L, Higgs D, et al. Pulse oximetry in a cohort study of sickle cell disease. Clin Lab Haematol 1997;19:17-22 https://doi.org/

21 Bland JM, Altman DG. Statistical methods for assessing agreement between two methods of clinical measurement. Lancet 1986;1:307-10.

22 Setty BNY, Stuart MJ, Dampier C, et al. Hypoxaemia in sickle cell disease: biomarker modulation and relevance to pathophysiology. Lancet 2003;362:1450-5.

23 Kirkham FJ, Hewes DKM, Prengler M, et al. Nocturnal hypoxaemia and central-nervous-system events in sickle-cell disease. The Lancet 2001;357:1656-9 https://doi.org/

24 Fitzgerald RK, Johnson A. Pulse oximetry in sickle cell anemia. Crit Care Med 2001;29:1803-6 https://doi.org/

25 Ortiz FO, Aldrich TK, Nagel RL, et al. Accuracy of pulse oximetry in sickle cell disease. Am J Respir Crit Care Med 1999;159:447-51.

26 Rackoff WR, Kunkel N, Silber JH, et al. Pulse oximetry and factors associated with hemoglobin oxygen desaturation in children with sickle cell disease. Blood 1993;81:3422-7.

27 Leach RM, Treacher DF. Oxygen transport-2. tissue hypoxia. BMJ 1998;317:1370-3.

28 Abdu A, Gómez-Márquez J, Aldrich TK. The oxygen affinity of sickle hemoglobin. Respir Physiol Neurobiol 2008;161:92-4 https://doi.org/

29 Caboot JB, Jawad AF, McDonough JM, et al. Non-Invasive measurements of carboxyhemoglobin and methemoglobin in children with sickle cell disease. Pediatr Pulmonol 2012;47:808-15 https://doi.org/

30 Feiner JR, Severinghaus JW, Bickler PE. Dark skin decreases the accuracy of pulse oximeters at low oxygen saturation: the effects of oximeter probe type and gender. Anesth Analg 2007;105:S18-23. 